\title{
MOUNTAIN TOURISM IN MACEDONIA: ASSESSMENT OF THE NATIONAL PARK "PELISTER"
}

DOI: http://dx.doi.org/10.18509/GBP.2017.30

UDC: 338.48-52:796.5(497.784)

\section{Nikola Dimitrov ${ }^{1}$ \\ Blagoja Markoski ${ }^{2}$ \\ Biljana Petrevska ${ }^{1}$ \\ Cane Koteski ${ }^{1}$}

${ }^{1}$ Faculty of Tourism and Business Logistics, University Goce Delcev - Štip, Macedonia

${ }^{2}$ Faculty of Natural Sciences and Mathematics, Institute of Geography, University Ss. Cyril and Methodius - Skopje, Macedonia

\begin{abstract}
Macedonia, as a mountain country, has extraordinary natural preconditions and possibilities for developing mountain tourism. Although it possesses different types of accommodation facilities (mountain lodges and houses; children and youth vocation facilities; boarding houses; etc.), Macedonia is facing many challenges. The article investigates the current level of mountain tourism development by elaborating the case of the National Park "Pelister" - Bitola (Macedonia). The analysis is based on qualitative research method and incorporates: a) Survey and interviews with mountaineers and responsible persons for mountain tourism development; and b) Secondary data analysis, by reviewing literature. Generally, it was concluded that the evaluated national park has numerous weaknesses that need to be addressed and various profound limiting factors that prevent its tourism development. Yet, by segmented and a tailor-made promotion, the National Park "Pelister" may gain many economic benefits thus overcoming the current scarce tourism valorization and at the same time, may boost mountain tourism development in Macedonia.
\end{abstract}

Keywords: Mountain tourism, Tourism development, Tourist product, Promotion.

\section{INTRODUCTION}

Many countries have realized the benefits for mountain tourism development. Yet, possessing mountains does not automatically mean gaining economic benefits. What is required for a successful mountain tourism development is actually a significant investment of time, money and efforts.

Mountains are often used as resources for developing tourism, in the first line by offering pleasure, relaxation, sport activities or even enjoying spiritual and psychological needs [2]. Many valuable information and experience on mountain tourism development may be gained from countries that implement mountain tourism, such as Austria, Switzerland, Germany, France, Italy, Slovenia, Serbia and others [2] and [3]. On the other side, very limited knowledge can be found in domestic literature related to the National Park "Pelister" [4] and [5].

The objective of this paper is to present some stylized facts on the current status of mountain tourism development in Macedonia, thus making an effort to explore and identify the major problems and weaknesses that need to be addressed. The focus is put 
on elaborating the case of the first national park in Macedonia - the National Park "Pelister" in Bitola, Macedonia. The Park is rich in many natural attractions favorable for developing various types of tourism activities, like hiking, mountaineering, skiing, biking, alpinism, etc.

The paper is structured in several parts. After the introductory part, Section 2 provides some stylized facts for the development of mountain tourism in Macedonia. Section 3 presents the background material on the elaborated case study, while Section 4 encompasses the research methodology. The analysis, results and discussion are noted in Section 5, while some future challenges and recommendations are presented in the final section.

This paper contributes to the limited academician work on development of mountain tourism in Macedonia. At the same time, the study provides recommendations to the key tourism players to introduce a new strategy and a vision of change for the National Park "Pelister". Its aim is also to encourage tourists to visit the investigated case study and to experience all it has to offer.

\section{MOUNTAIN TOURISM IN MACEDONIA}

Macedonia is a country rich on mountains that encompass $20,813 \mathrm{~km}^{2}$ or $81 \%$ from the entire territory, with an average high of $829 \mathrm{~m} \mathrm{[6].} \mathrm{The} \mathrm{largest} \mathrm{portion} \mathrm{of} \mathrm{the} \mathrm{territory} \mathrm{is}$ covered by mountains with $11,044 \mathrm{~km}^{2}(43 \%)$, the hills cover $9,769 \mathrm{~km}^{2}(38 \%)$, and the valleys have 4,900 $\mathrm{km}^{2}(19 \%)$. Macedonia has 26 mountain ranges with 40 mountains, out of which 13 are higher than 2,000 m.

The beginnings of mountain tourism are noted in the end of the 1960s when the first ski centers are build (first "Popova Šapka" and "Mavrovo", and than "Pelister" and "Kruševo"). However, due to the collapse of former Yugoslavia and the war conflicts in 1990 s, the mountain tourism losses its importance. Particularly due to the war conflict in 2001, Macedonia was faced with serious problems in terms of building and maintaining the winter infrastructure (the ski-elevators, funiculars etc.). Just recently, tourists mainly from the neighboring countries (Albania, Greece, Kosovo, Serbia and Bulgaria) have started to visit the winter ski centers in Macedonia.

It is estimated that around 30 winter sport centers may be formed in the high mountains in Macedonia, with a total denivelation of the ski tracks of $115 \mathrm{~km}$. The maximal capacity of all ski centers is around 115,000 skiers. If we add the number of non-skiers but just visitors to the ski centers, than the number increases to 230,000 total visitors.

Today, based upon the official statistical data, seven ski centers are active: on mountain Šar Planina (ski center "Popova Šapka"), on mountain Bistra (ski center "Zare Lazarevski" - Mavrovo), Baba mountain with Pelister (ski center "Kopanki" and "Streževo - Nižepole"), mountain Kožuv (ski center "Kožuv"), Buševa mountain (ski center "Stanič") and Osogovo mountain (ski center "Ponikva"). Besides skiing, these mountains offer possibilities for active mountaineering due to dormitories, tracks for mount-biking, paragliding, etc. According to the official data, the seven ski centers poses 42 ski-elevators and funiculars, 4 dormitories, over 20 hotels and guest houses, large number of hotels etc.

However, based on the objective screening on the field, the current conditions for developing mountain tourism in Macedonia, are completely different. Due to lack of finance, many of the above mentioned ski centers are in poor condition with large infrastructural problems. Consequently, four out of seven ski centers are closed ("Kopanki", "Streževo - Nižepole", "Kožuv" and "Ponikva"). At the same time, large 
number of mount houses are not in function. One may conclude that the mountain tourism in Macedonia is facing serious problems. Many of detected weaknesses and problems are going to be elaborated through the case of the National Park "Pelister" - Bitola.

\section{BACKGROUND MATERIAL ON THE NATIONAL PARK "PELISTER"}

The National Park "Pelister" is located in the Southwest part of Macedonia as a part of the Baba mountain. The park encompasses $171.5 \mathrm{~km}^{2}$ thus representing $43 \%$ of the mountain. The longitude is $22 \mathrm{~km}$, and the amplitude is $14 \mathrm{~km}$. The park starts from 891 $\mathrm{m}$ above the sea level, and spreads to 2,601 m. The average high is 1,746 m. Based on that, the park belongs to the group of highly mountaineered national parks with around 50 picks over $2,000 \mathrm{~m}$. being simultaneously the most south mountain from an Alpine kind [8].

Pelister is a national park since 1948, due to the presence of the endemic Pinus peuce, the variety of the geology, specific climatic and hydrographic conditions, as well as the endemic flora and fauna. The Baba mountain along with the pick of Pelister has many anthropogenic values in terms of archeological sites, midlevel churches and monasteries, memorial sites and so forth.

Tourism infrastructure in the National Park "Pelister" consists of three main roads, funicular, three ski elevators, several hiking trails, two dormitories ("Kopanki" and "Dimitar Ilievski" at the Golemo Ezero), one rest house ("Pelister"), one hotel ("Molika"), several villas, a mountain house, an information center, several excursion places, two monasteries, six churches, many biking trails etc. During through the year, many events are taking place ("Pelister's skiing", "Recreational biking race") and mountain marches (in the honor of "Dimitar Ilievski - Murat", and other).

When speaking in national frames, the National Park "Pelister" primarily is known as mountain tourist destination with unique natural characteristics favorable for mountaineering, sport and education, thus offering active holiday and stay. Consequently, the National Park "Pelister" offers great potentials for developing mountain, sport, educational and recreational tourism [11]. However, since few years ago, "Pelister" is facing serious problems. Namely, in 2013, the oldest mountain dormitory "Kopanki" was ruined in fire, and since 2016 the dormitory "Pelister" is closed. Furthermore, several attractive locations have been ruined and the hiking signs are old and damaged. All this resulted in decrease in number of mountaineers and hikers in the Park.

\section{METHODOLOGY AND RESEARCH FRAME}

The main aim of the research is to present the potential and current condition of the National park "Pelister" in the line of developing mountain tourism. The research is based on applying quantitative and qualitative methods for determining the value and tourism attractiveness for mountain tourism, particularly for mountaineering and skiing [7] and [9].

In order to pose answers to the research question: What is the future of the mountain tourism in the National Park "Pelister", the study presents the findings from the interview with responsible officials from the Park, managers of the mountain clubs from Bitola, current and former keepers of mountain dormitories, mountaineers, hikers and skiers.

\section{ANALYSIS, FINDINGS AND DISCUSSION}

The main variable applied in the analysis is the number of beds, for the period 1926-2015. Due to the lack of official data on the number of guests, visitors or tourists in the Park, 
the authors apply partial data obtained from other studies on the National Park "Pelister", as well as from the survey among local officials.

During 1960s, the number of visitors ranged between 2,040 in 1962, to 6,033 in 1969. In 1970s, some slight oscillation is noted starting from 2,713 visitors in 1971, to 4,141 in 1975 , ending with 5,982 visitors in 1979 [10]. The maximal number of visit is noted in 1985 with around 10,000 tourists representing one-third from the total number of tourists that visited Bitola. In the early 1990s, this number is significantly reduced to around 5,000 tourists. Yet, as result to the extension of the accommodation capacity with the new hotel "Molika" in 1995, the number of tourists increased and reached nearly 7,500. This data is confirmed by the officials from the Park during the interview process (Table 1).

Table 1. Maximal number of tourists and overnights

in accommodation facilities located in the National Park "Pelister"*

\begin{tabular}{|c|c|c|c|}
\hline \multirow{2}{*}{$\begin{array}{l}\text { Accommodation } \\
\text { facility }\end{array}$} & \multicolumn{2}{|c|}{ Maximum per year* } & \multirow{2}{*}{ Note } \\
\hline & Tourists & Overnights & \\
\hline "Molika" & 7,800 & 15,000 & 4* hotel. Capacity of 136 beds \\
\hline Dormitory "Pelister" & 2,500 & 17,500 & $\begin{array}{l}\text { Capacity of cca. } 300 \text { beds. Works } \\
\text { only during seasons. As of } 2016 \text {, } \\
\text { closed }\end{array}$ \\
\hline Dormitory “Kopanki” & 750 & 1,200 & $\begin{array}{l}\text { Capacity of } 110 \text { beds. As of } 2013 \text {, } \\
\text { closed }\end{array}$ \\
\hline $\begin{array}{l}\text { Domritory "Dimitar } \\
\text { Ilievski" at the Great } \\
\text { Lake }\end{array}$ & 400 & 600 & $\begin{array}{l}\text { Capacity of } 45 \text { beds. Works during } \\
\text { seasons. Infrastructural problems } \\
\text { (water, electricity, toilets etc.). }\end{array}$ \\
\hline $\begin{array}{l}\text { Camp houses and } \\
\text { villas "Begova Češma" }\end{array}$ & $\mathrm{n} / \mathrm{a}$ & $\mathrm{n} / \mathrm{a}$ & Capacity cca. 120 beds. Out of work. \\
\hline Total: & 11,600 & 34,600 & In $2015,7,500$ tourists \\
\hline
\end{tabular}

Note: *Maximal number of tourists and overnights refers to the middle of $1980 \mathrm{~s}$, with an exception of hotel "Molika" (being built in 1995).

Out of the borders of the park, there a dozen of other accommodation and tourist facilities located in the wider vicinity. Among them, for the interest of developing mountain tourism is the center "Streževo-Pelister" located near the village of Nižepole. This center dates from 1984 and is mainly used for accommodating mountaineers and skiers. In the 1980s and 1990s, between 2,000 and 5,000 guests visited the center on yearly basis.

Figure 1. TALC model of the National Park "Pelister", 1926-2015

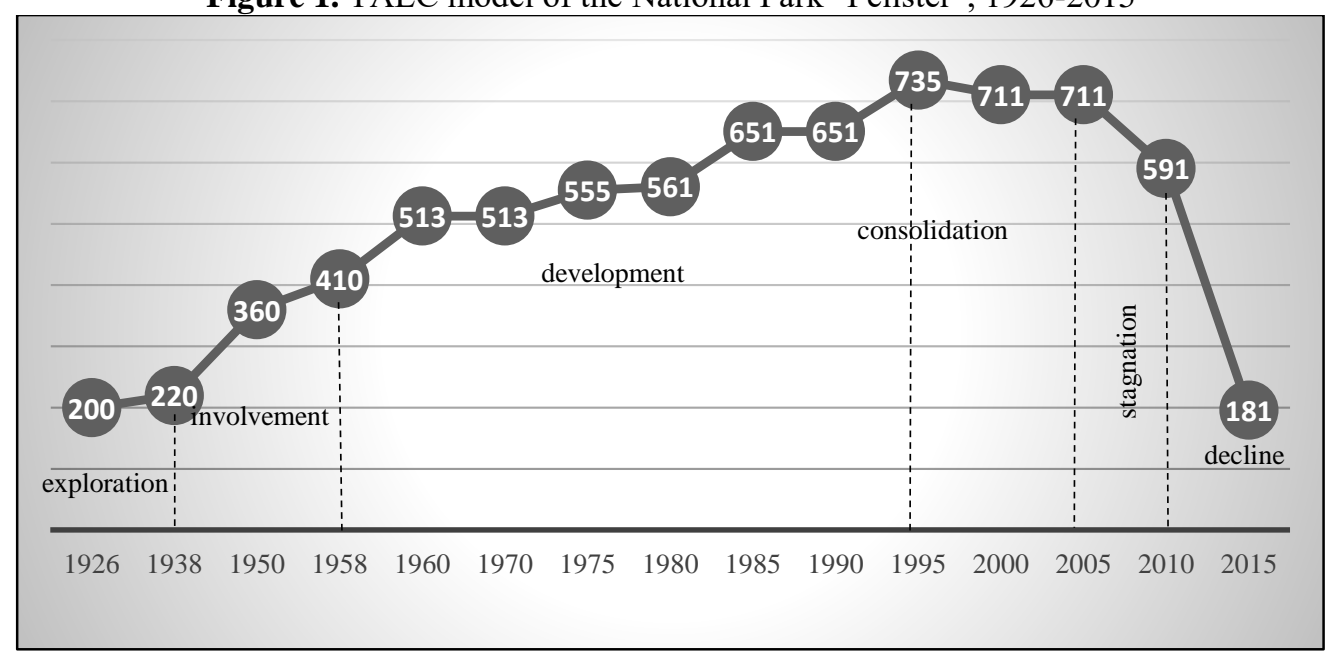


Figure 1 presents the number of beds in the National Park "Pelister" for the period 19262015 according to the TALC model [1], thus representing the life cycle of the Park [12]. Based on that, six phases of the life cycle are identified: exploration, involvement, development, consolidation, stagnation and decline.

The phase of exploration spreads over the period 1926-1938. It starts with the opening of the dormitory "Štamparevac" at that time having 200 beds, and later on (in 1930s) is expanded with fourth smaller cabin. At this phase, the capacity of the Park counts 220 beds.

The phase of involvements starts with the Second World War and lasts until 1958. During this period, "Begova Češma" and "Kopanki" are renovated after their total demolition in the war. In 1954, a new dormitory named "Golemo Ezero" is build. At this phase, the capacity of the Park has enlarged for $86 \%$, or additional new 190 beds, thus counting a total of 410 beds.

The phase of development is the longest, starting from 1959-1995, encompassing a period of 35 years. "Kopanki" and "Golemo Ezero" are renovated and several new facilities are build. The number of camp houses increases to five, so the capacity is 40 beds. During this phase, the new hotel "Molika" is built (136 beds), thus contributing to 735 beds in total, representing an increase of $79 \%$. At this phase, the Park reaches its peak point in terms of visitors from Macedonia, as well as from the neighboring countries. The ski centers "Kopanki" and "Streževo - Nižepole" are built and many sport events and competitions are organized.

The phase of consolidation lasts from 1996 until 2005 when a slight decrease in the number of beds is registered i.e. $3 \%$ decrease or 24 beds. However, the accommodation capacity in the Park is still maintained despite the certain oscillations in visits.

The phase of stagnation starts in 2006 and ends in 2010. The main characteristic is the decrease for 120 beds, from 711 to 591 . All camp houses are closed, along with some parts of the "Streževo" pension.

During the last phase of the life cycle of the Park, a decline is noted erupting with the catastrophic fire in 2013 when the dormitory "Kopanki" was ruined. The decline continued in the next years resulting in closing of dormitory "Pelister". Consequently, the number of beds in the Park drastically reduced for $69.4 \%$ i.e. from 591 to 181 beds. Today, the only available accommodation facilities within the Park are "Molika" and "Dimitar Ilievski" at the Great Lake.

Due to the lack of sufficient accommodation capacity, the number of visitors to the Park dramatically dropped. One may conclude that after the six phases (Figure 1) in the period 1926-2015, now obviously the Park is at the starting point facing the exploration phase.

Based on the field research and the objective screen, the authors created Table 2 and Table 3 , which pose summarized results from valorization of the accommodation facilities located in the Park by following adjusted methodology [3]. 
Socio-economic geography

Table 2. Valorization of accommodation facilities located in the National Park "Pelister"

\begin{tabular}{|c|c|c|c|c|c|c|c|}
\hline \multirow[b]{2}{*}{ Accommodation facility } & \multicolumn{5}{|c|}{ Technical infrastructure } & \multirow[b]{2}{*}{ Period } & \multirow[b]{2}{*}{ Score* } \\
\hline & 离 & 冚 & $\stackrel{u}{3}$ & 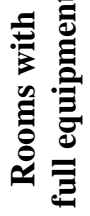 & 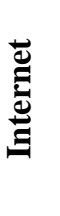 & & \\
\hline $\begin{array}{l}\text { "Kopanki" } \\
\text { Before the fire (until } \\
28.01 .2013 \text { ) }\end{array}$ & + & + & + & - & - & All year & 2 \\
\hline After the fire (2016) & - & - & - & - & - & Out of work & $\mathbf{0}$ \\
\hline "Golemo Ezero" & 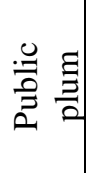 & 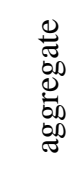 & 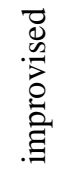 & - & - & season & 1 \\
\hline "Pelister" Until 2015 & + & + & + & + & + & season & 2 \\
\hline As of 2016 & + & + & + & - & + & Out of work & $\mathbf{0}$ \\
\hline "Begova Češma" (until 2005) & + & + & + & - & - & season & 2 \\
\hline "Begova Češma" (as of 2006) & $\mathrm{n} / \mathrm{a}$ & $\mathrm{n} / \mathrm{a}$ & $\mathrm{n} / \mathrm{a}$ & $\mathrm{n} / \mathrm{a}$ & $\mathrm{n} / \mathrm{a}$ & Out of work & $\mathbf{0}$ \\
\hline "Molika" & + & + & + & + & + & All year & 3 \\
\hline
\end{tabular}

Note: Based upon survey and interviews on visitors. The ecological criteria are not covered.

* Score $=$ tourism valorization $0-3$, whereas: $0=$ undefined tourism value; $1=$ low tourism value; $2=$ middle tourism value; and $3=$ high tourism value

Table 3. Valorization of the environment of accommodation facilities located in the National Park "Pelister"

\begin{tabular}{|c|c|c|c|c|c|c|c|c|}
\hline \multirow[b]{2}{*}{ Accommodation facility } & \multicolumn{7}{|c|}{ Technical infrastructure } & \multirow[b]{2}{*}{ Score* } \\
\hline & 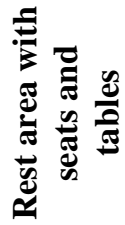 & 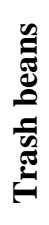 & 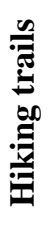 & 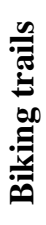 & 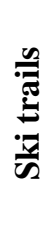 & $\frac{\sqrt[n]{\sigma}}{\stackrel{0}{\sigma}}$ & 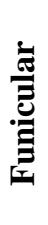 & \\
\hline $\begin{array}{l}\text { "Kopanki" } \\
\text { Before the fire (until 28.01.2013) }\end{array}$ & + & + & + & - & + & + & + & 2 \\
\hline After the fire (2016) & - & - & + & - & + & + & + & $\mathbf{0}$ \\
\hline "Golemo Ezero" & + & + & + & + & - & - & - & 1 \\
\hline $\begin{array}{l}\text { "Pelister" } \\
\text { Until } 2015\end{array}$ & + & + & + & + & + & + & - & 2 \\
\hline As of 2016 & + & + & + & - & - & - & - & $\mathbf{0}$ \\
\hline "Begova Češma" (until 2005) & + & + & + & - & + & - & + & 2 \\
\hline "Begova Češma" (as of 2006) & - & - & + & - & + & - & + & $\mathbf{0}$ \\
\hline "Molika" & + & + & + & + & + & + & + & 3 \\
\hline
\end{tabular}

Note: Based upon survey and interviews on visitors. The ecological criteria are not covered.

* Score $=$ tourism valorization $0-3$, whereas: $0=$ undefined tourism value; $1=$ low tourism value; $2=$ middle tourism value; and $3=$ high tourism value

Based on Table 2 and Table 3, it can be concluded that currently, only hotel "Molika" and its environment have notable scoring. Namely, the score 3 refers to high tourism value, which does not mean that the potentials for developing mountain tourism are completely utilized. 


\section{CONCLUSIONS AND RECOMMENDATIONS}

After the fire of dormitory "Kopanki" in 2013, along with the bad conditions of the dormitory "Dimitar Ilievski" at the Great Lake location, the number of mountaineers who traditionally were visiting the Park, rapidly declined. As of 2016, the dormitory "Pelister" is also out of work, while the ski club "Pelister" is closed for the past decade. Consequently, the mountaineering and the ski sport in Pelister are facing serious crisis. The only way out is detected in the hotel "Molika", while all other accommodation facilities either are closed, or are facing to be closed.

Based on the field research, the study recommends undertaking immediate actions for renovation of the old dormitories, as well as building new facilities. There is also an urgent need to enlarge and renew the "Streževo" pension, as well as to build several new funiculars and ski elevators.

Further on, the study recommends introduction of tourism statistics in order to promptly register the visitors of the National Park "Pelister". By this, the national parks may be added as special places of interest or tourist attractions within a certain tourist area. Hence, significant indicators for planning development of mountain tourism may be available, thus contributing to the process of initiating sustainability of the parks.

The public enterprise "Pelister" should pay special attention to the development of mountain tourism, which up-to-date was not the case. Just as a reminder, it should be pointed out that mountaineering in Palister had a tradition for almost a century, so the National Park "Pelister" should work on continuation of this tradition, generally by maintaining the current accommodation facilities, as well as by initiating construction of new ones.

\section{REFERENCES}

[1] Butler, R. W. (2009) Tourism in the future: Cycles, waves or wheels?, Futures, 41(6), 346-352.

[2] Bjeljac, Ž., Brankov, J., Jovičić, D., Ćurčić, N. \& Terzić, A. (2012) Valorization of natural and anthropogenic tourist potentials in underdeveloped regions of transition countries. TTEM, 8(3), 1237-1250.

[3] Boengiu, V. (2012) Evaluation of tourism resources in the Iron Gates natural park in order to identify the potential of tourism development. Annals of the University of Oradea, Geography Series, Vol.22 (2):234-240.

[4] Dimoski, B. (1981). Village tourism in the hilly-mountain areas in the West Macedonia, Conference proceedings from the symposium "Natural and socio-geographic problems in the hilly mountain areas", 13-15 June 1980, Berovo, Macedonia, 223-233 (in Macedonian).

[5] Dimitrov, N. (1998). Bitola - urban geographic development, Bitola, 202-203 (in Macedonian).

[6] Dimitrov, N. \& Koteski, C. (2015). Tourism geography, Stip (in Macedonian).

[7] Du Cros, H. (2001). A new model to assist in planning for sustainable cultural heritage tourism. International Journal of Tourism Research, 3(2), 165-170.

[8] Group of authors. (2008). Monography 50 years of the National Park "Pelister", Bitola (in Macedonian).

[9] Hadžić, O., Marković, B. S., Vasiljević, Nedeljković, M. (2010). A dynamical model for assessingtourism market atractiveness of a geos. Geotrends 2010, Novi Sad. 
[10] Kostovski, V. (1976). Tourism potentials of Bitola, Conference proceedings of the symposium "Tourism and environmental protection", Skopje, 167-170.

[11] Markoski, B. \& Dimitrov, N. (2013). National Park "Pelister" and Baba Mountain, Hiking - Tourist Map, Geomap, Skopje, (Maps: Walking and hiking trails of National Park „Pelister").

[12] Petrevska, B. \& Collins-Kreiner N. (2016). Double Life Cycle: Determining Tourism Development in Macedonia. Journal of Tourism and Cultural Change, DOI: 10.1080/14766825.2016.1150288. 